Article

\title{
Suppression of Hepatocyte Nuclear Factor $4 \alpha$ by Long-term Infection of Hepatitis B Virus Contributes to Tumor Cell Proliferation
}

\author{
Soree Park ${ }^{+}$(D), Yea Na Ha ${ }^{\dagger}$, Mehrangiz Dezhbord, Ah Ram Lee, Eun-Sook Park, \\ Yong Kwang Park, Juhee Won, Na Yeon Kim, Soo Yeun Choo, Jae Jin Shin, Chang Hyun Ahn \\ and Kyun-Hwan Kim *(D)
}

\begin{abstract}
Department of Pharmacology, Center for Cancer Research and Diagnostic Medicine, IBST, School of Medicine, Konkuk University, Seoul 05029, Korea; rhd37@naver.com (S.P.); clean1701@naver.com (Y.N.H.); asal_dejbord@yahoo.com (M.D.); ahram2g@naver.com (A.R.L.); espark97@gmail.com (E.-S.P.); yk1029@korea.kr (Y.K.P.); 1wonjuhee@hanmail.net (J.W.); michaela3310@naver.com (N.Y.K.); michellechoo@naver.com (S.Y.C.); 362whe12@naver.com (J.J.S.); quek689@gmail.com (C.H.A.)

* Correspondence: khkim10@kku.ac.kr; Tel.: +82-2-2030-7833; Fax: +82-2-2049-6192

+ These authors contributed equally to this work.
\end{abstract}

Received: 30 December 2019; Accepted: 29 January 2020; Published: 31 January 2020

check for updates

\begin{abstract}
Hepatitis B virus (HBV) infection is a major factor in the development of various liver diseases such as hepatocellular carcinoma (HCC). Among HBV encoded proteins, HBV X protein $(\mathrm{HBx})$ is known to play a key role in the development of HCC. Hepatocyte nuclear factor $4 \alpha$ $(\mathrm{HNF} 4 \alpha)$ is a nuclear transcription factor which is critical for hepatocyte differentiation. However, the expression level as well as its regulatory mechanism in HBV infection have yet to be clarified. Here, we observed the suppression of HNF4 $\alpha$ in cells which stably express HBV whole genome or HBx protein alone, while transient transfection of HBV replicon or HBx plasmid had no effect on the HNF4 $\alpha$ level. Importantly, in the stable HBV- or HBx-expressing hepatocytes, the downregulated level of HNF4 $\alpha$ was restored by inhibiting the ERK signaling pathway. Our data show that HNF $4 \alpha$ was suppressed during long-term HBV infection in cultured HepG2-NTCP cells as well as in a mouse model following hydrodynamic injection of pAAV-HBV or in mice intravenously infected with rAAV-HBV. Importantly, HNF4 $\alpha$ downregulation increased cell proliferation, which contributed to the formation and development of tumor in xenograft nude mice. The data presented here provide proof of the effect of $\mathrm{HBV}$ infection in manipulating the $\mathrm{HNF} 4 \alpha$ regulatory pathway in $\mathrm{HCC}$ development.
\end{abstract}

Keywords: Hepatitis B virus; hepatocyte nuclear factor $4 \alpha$; long-term infection; ERK signaling pathway

\section{Introduction}

Chronic Hepatitis B Virus (HBV) infection is one of the global health problems. The World Health Organization estimates that approximately 240 million people worldwide are chronically infected, despite the availability of an effective HBV vaccination program. Chronic Hepatitis B (CHB) infection is considered as a serious risk factor in the development of liver cirrhosis and hepatocellular carcinoma (HCC) [1].

As the fifth most common type of human liver cancer, malignant HCC is the cause of many cancer-related deaths globally [2]. Over 500,000 people worldwide are affected by HCC and the incidence is increasing [3]. The lack of early diagnostic markers and effective therapies are two significant impediments to controlling the disease. HCC is mostly prevalent in Africa and Eastern Asia due to chronic HBV infection [2]. However, the mechanism by which HBV infection contributes to the development of HCC remains unclear. 
HBV is an enveloped virus and a member of the Hepadnaviridae family, that contains a partially double-stranded DNA genome $3.2 \mathrm{~kb}$ in length. The HBV genome contains four genes (core, surface, $\mathrm{X}$, and polymerase). $\mathrm{HBV} \mathrm{X}$ protein $(\mathrm{HBx})$ is a small trans-activator protein with a molecular mass of $16.5 \mathrm{kDa}$ which activates the transcription of HBV [4-6]. Increasing evidence suggests that the HBx protein plays an important role in the development of HCC $[7,8]$.

Hepatocyte nuclear factor $4 \alpha$ (HNF4 $\alpha$ ) is a protein which belongs to the nuclear receptor superfamily and binds to DNA as a homodimer. HNF4 $\alpha$ is expressed in hepatocytes and plays a critical role in the transcription and expression of many liver-specific genes $[9,10]$. It is also essential for the hepatic epithelium formation during embryonic development. Moreover, HNF4 $\alpha$ is known as a key tumor suppressor that inhibits the progression of HCC. Thus, there are several studies that HNF4 $\alpha$ expression level is suppressed in human HCC tissue compared to other adjacent noncancerous tissues [11-13].

Previous studies have examined the expression level of HNF4 $\alpha$ during HBV infection. However, HNF4 $\alpha$ expression level varies among different studies. HNF4 $\alpha$ was shown to be downregulated in rat primary hepatocyte transfected with HBV plasmid [14], and in a human hepatoma cell line transfected with HBV plasmid [15]. In these cases, the level of HNF4 $\alpha$ protein was examined in the early stage of HBV infection. Contrarily to these reports, the expression of HNF4 $\alpha$ was enhanced in chronic HBV-infected patients [16]. Thus, in HBV infection, the level of HNF4 $\alpha$ has yet to be clarified.

Previous reports have shown that the rat sarcoma virus (Ras)/Raf/MEK/ERK signaling pathway, the c-Jun N-terminal kinase (JNK) pathway and the phosphoinositide 3-kinase (PI3K)/AKT signaling pathway are the major signaling pathways regulating cell proliferation and differentiation in HCC cells $[17,18]$. Among these, the ERK signaling pathway is one of the main pathways in HCC which is associated with cell proliferation [19] and previous studies have revealed that HBx activates the ERK signaling pathway [20-22].

Previously, HNF4 $\alpha$ suppression was shown to be associated with the AKT signaling pathway [14] in primary rat hepatocyte. However, the mechanism of HNF4 $\alpha$ suppression in human hepatocytes has not yet been clearly identified. The aim of this study was to investigate the effect of HBV on the expression of HNF4 $\alpha$ in human hepatocytes and the role of HNF4 $\alpha$ suppression in tumor cell proliferation in vivo and in vitro. We found that the expression level of HNF4 $\alpha$ was suppressed by $\mathrm{HBV}$ only in long-term infection. Our data demonstrate that HNF4 $\alpha$ downregulation contributes to the formation and development of tumor in xenograft nude mice.

\section{Results}

\subsection{Expression of HNF4 $\alpha$ Protein is Significantly Downregulated in Long-term Expression of HBV}

First, we determined the expression level of HNF4 $\alpha$ using transient as well as stable HBV expression human hepatoma cell lines. We measured the level of HNF4 $\alpha$ after transfection with HBV1.2mer plasmid in HepG2 cell line. At the transiently transfected state, there was no significant effect on the level of HNF4 $\alpha$ up to 2 days post transfection (Figure 1a). However, in the HepG2.2.15 cell line which stably expresses the HBV genome from chromosomally integrated HBV sequence, the level of HNF4 $\alpha$ was suppressed as compared to the parental HepG2 cell (Figure 1b). In addition, a slight reduction was observed in the level of HNF1 $\alpha$ after stable expression of HBV. In contrast, the expression level of other nuclear transcription factors such as HNF3 $\beta$, and C/EBP $\alpha$ did not alter after the transient or stable expression of the HBV genome (Figure $1 \mathrm{a}, \mathrm{b}$ ).

In the HepAD38 cell line, HBV genome expression is under the control of a tetracycline inducible promoter. Therefore, tetracycline withdrawal induces viral RNA and secretion of virus-like particles into the supernatants. After 7 days of tetracycline removal, the level of HNF $4 \alpha$ was suppressed in the induced HepAD38 cell line compared to the control cells, maintained in tetracycline containing medium (Figure 1b).

As shown in panel $\mathrm{C}$, the level of $\mathrm{HBV}$ core protein as a HBV expression marker was measured up to 2 weeks post induction. The core protein formation started from 48 to $72 \mathrm{~h}$ after tetracycline removal 
and was gradually accumulated in the cells. The amount of HNF4 $\alpha$ protein, however, remained constant up to 4 days post HBV induction and between days 5 and 14, there was a considerable reduction in the signal intensity of the HNF $4 \alpha$ protein. An inverse correlation between the expression level of HBV and HNF4 $\alpha$ was observed in the HepAD38 cell line (Figure 1c). Therefore, at later time points following the continuous expression of HBV, the level of HNF4 $\alpha$ began to decrease, indicating that the level of HNF4 $\alpha$ decreased in long-term expression of HBV.

(a)

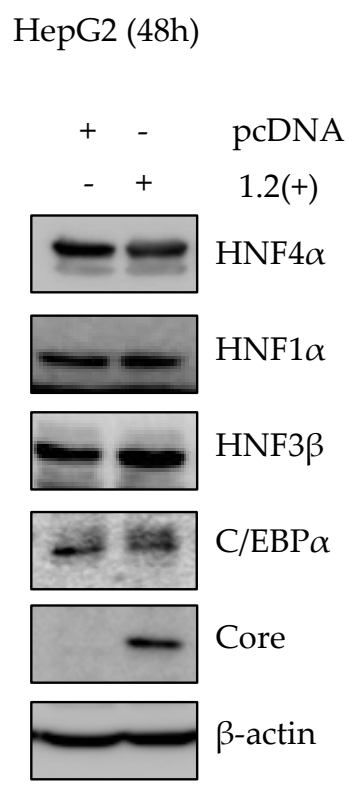

(b)

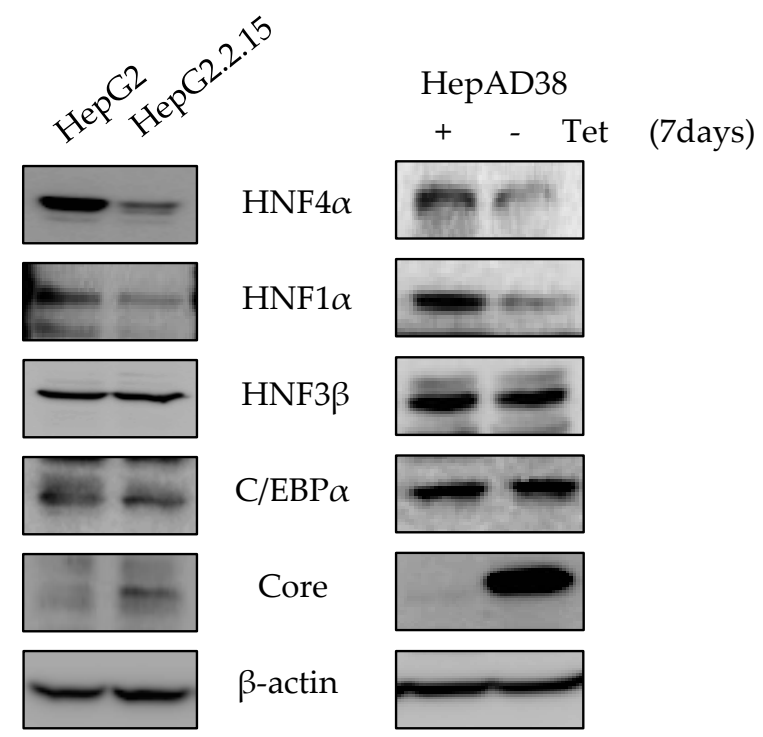

(c)

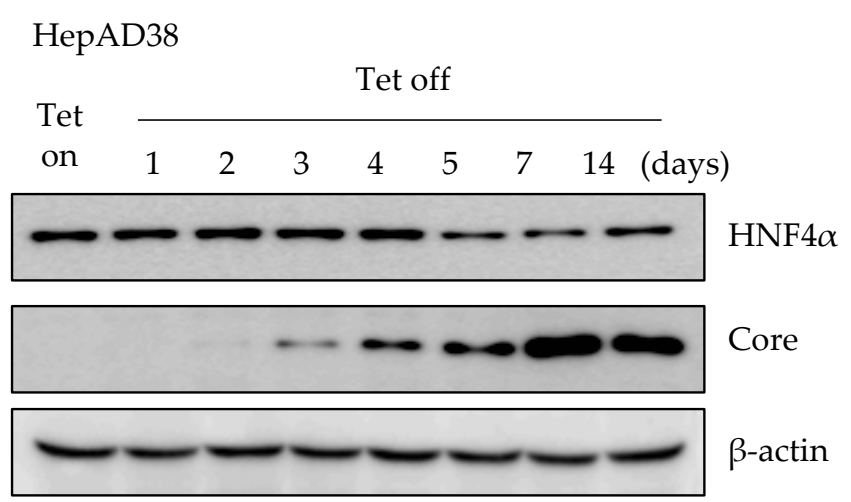

Figure 1. Expression level of HNF4 $\alpha$ in early stage and long-term of HBV expression in vitro. (a) HBV 1.2mer $(1.2(+))$ plasmid was transfected into the HepG2 cells. Cells were then harvested at $48 \mathrm{~h}$ after transfection. The level of proteins was analyzed by Western blot. (b) Expression levels of transcription factors in HepG2, HepG2.2.15, and HepAD38 cell lines was determined by Western blot. In HepAD38 cell line, the complete medium without tetracycline, was used for 7 days in order to induce HBV production. (c) The expression level of HNF4 $\alpha$ in HepAD38 cell line at indicated time points was determined in the absence of tetracycline. The data represent the results from three independent experiments.

\subsection{HBx Protein is Responsible for the Suppression of HNF4a in Long-term HBV Expression}

It is known that $\mathrm{HBx}$ is a regulatory protein and associated with the expression of HNF4 $\alpha$ in rat primary hepatocyte which does not support HBV infection [14]. Therefore, we investigated the effect of HBx protein on HNF4 $\alpha$ level in human hepatocytes. As a long-term HBx expression model, 
we generated a HepG2-X stable cell line which stably overexpress HBx protein. As shown in Figure 2a, the level of HNF4 $\alpha$ protein in HepG2-X stable cell line was suppressed compared to the control, HepG2-pc cell. We next determined the HNF4 $\alpha$ level in the presence or absence of HBx protein in a transient transfection using replication-competent wild type HBV 1.2mer (1.2(+)) and HBV 1.2mer X-null (1.2(-)) plasmids. HBV 1.3mer (1.3(+)) plasmid contains double copy of the HBx gene and were used in parallel along with the HBV 1.3mer X-null plasmid (1.3(-)). In a transient state, there were no changes in the level of HNF4 $\alpha$ after $48 \mathrm{~h}$ of transfection with each plasmid (Figure $2 \mathrm{~b}$ ). In addition, overexpressing HBx by transfection of HBx plasmid to HepG2 cells had no effect on the level of HNF4 $\alpha$ (Figure 2c). As a result, suppression of HNF4 $\alpha$ was only observed in long-term of expression of the HBx protein.

(a)

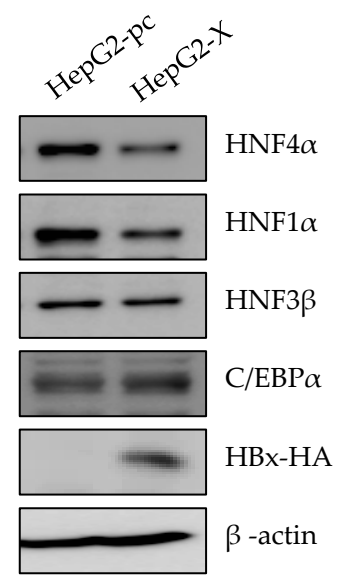

(b) HepG2 (48h)

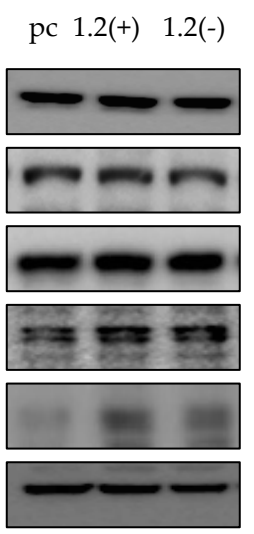

pc $1.3(+) 1.3(-)$

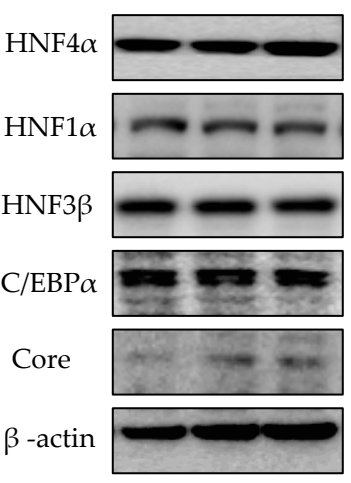

(c) HepG2 (48h)

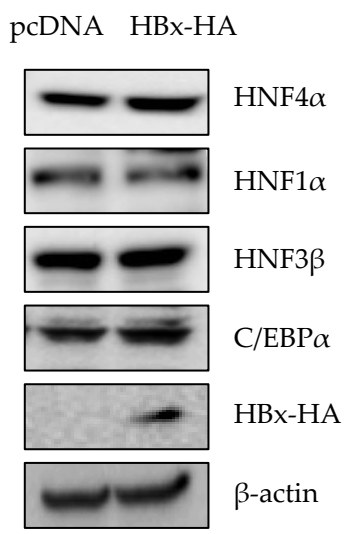

Figure 2. Suppression of HNF4 $\alpha$ via HBx protein in long-term expression of HBV. (a) The level of proteins in HepG2-pc, HepG2-X cell lines were analyzed by Western blot. (b,c) HepG2 cells were transfected with $2 \mu \mathrm{g}$ of indicated plasmids per well in a 6-well plate and harvested after $48 \mathrm{~h}$. The levels of proteins were determined by Western blotting. The data represent the results from three independent experiments.

\subsection{ERK Signaling Pathway is Associated with the Downregulation of HNF4 $\alpha$}

To examine the mechanism of HNF4 $\alpha$ suppression, we investigated the mRNA level of HNF $4 \alpha$ by quantitative real-time PCR (Figure 3a). The mRNA level of HNF4 $\alpha$ decreased in HepG2.2.15 compared to HepG2, but not in HBV 1.2mer transfected cells (Figure 3a, left). Similarly, at one-week post HBV induction the mRNA level of HNF4 $\alpha$ reduced in HepAD38 cells as compared to the cells maintained with tetracycline (Figure 3a, right). These results are consistent with the results of protein level (Figure 1a,b), suggesting that the suppression of HNF4 $\alpha$ occurs at the transcriptional level.

Having shown that HNF4 $\alpha$ is suppressed at the transcriptional level, we then investigated the signaling pathway that is associated with this suppression by interrupting different signaling pathways. Accordingly, the inhibitors for ERK (U0126), AKT (LY294002, Rapamycin), JNK (SP600125), p38 (SB203580), and mTOR/AKT (Rapamycin) were treated in HepG2.2.15 and HepAD38 cells. The suppressed mRNA level of HNF4 $\alpha$ was recovered only following the inhibition of ERK signaling pathway (U0126) in both cell lines (Figure 3b, left and right). Other signaling pathway inhibitors had no significant effect on HNF4 $\alpha$ expression level. 
(a)

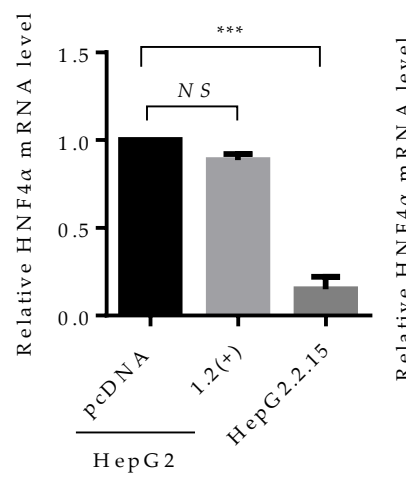

(c)

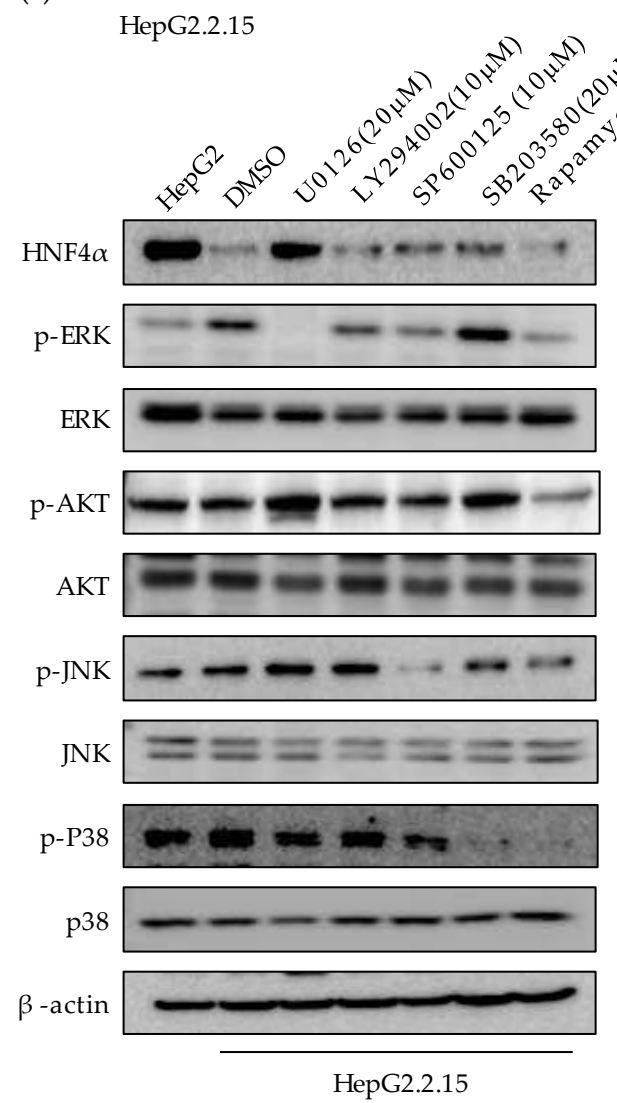

(d)

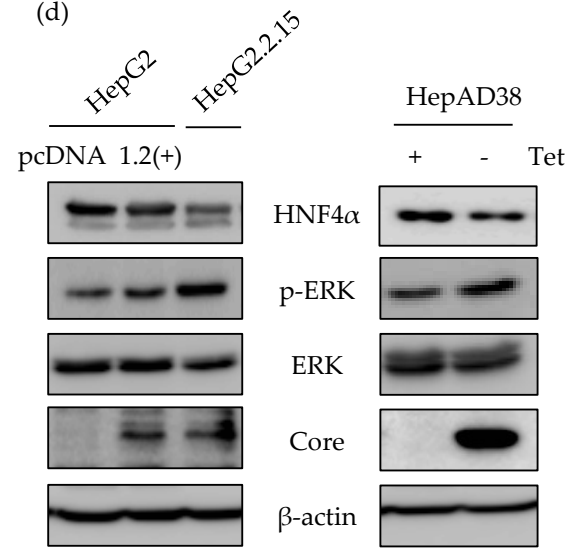

(b)

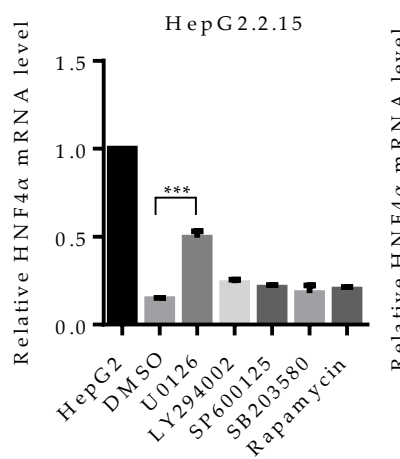

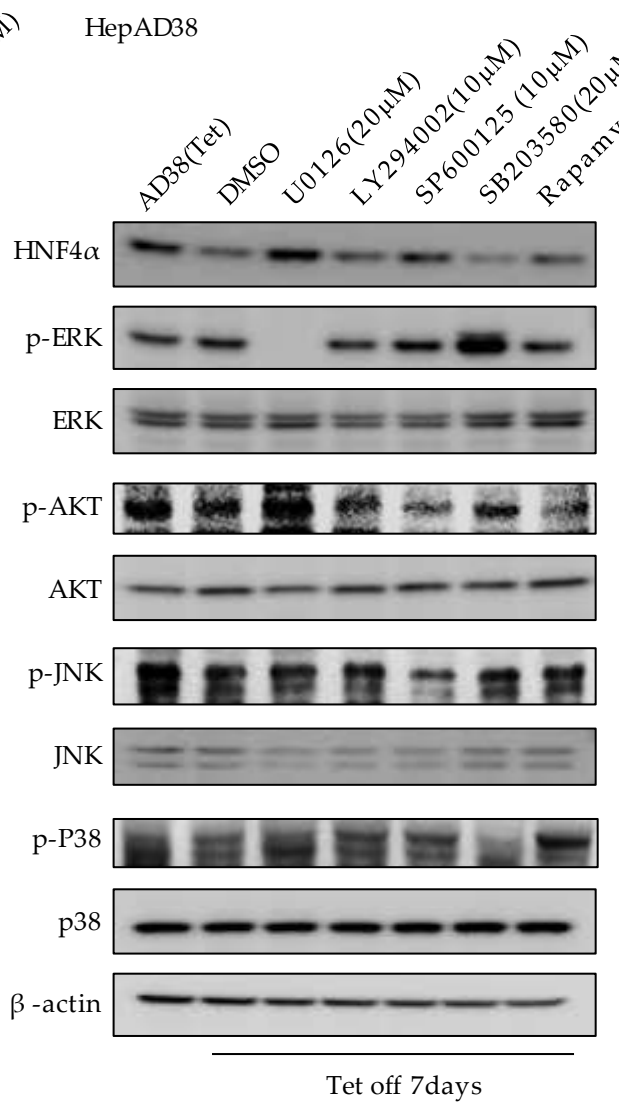

(e)

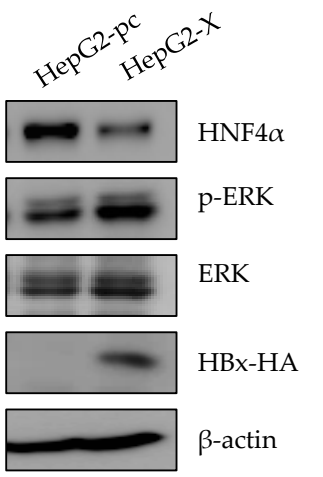

HepG2-pc HepG2-X

++ U 0126

- - - HNF4 $\alpha$

$=\quad$ p-ERK

ERK

HBx-HA

$\longrightarrow \beta$-actin 
Figure 3. Involvement of ERK signaling pathway in suppression of HNF4 $\alpha$. (a) The expression level of HNF $4 \alpha$ was analyzed by qRT-PCR analysis in human liver cancer cell lines. (b) HepG2.2.15 and HepAD38 cells were treated with U0126, LY294002, and SP600125 (10 $\mu \mathrm{M}), 20 \mu \mathrm{M}$ of SB203580 and $100 \mathrm{nM}$ of Rapamycin at $24 \mathrm{~h}$ before harvest. The relative level of HNF $4 \alpha$ mRNA was determined by qRT-PCR. ${ }^{* *} p<0.01,{ }^{* * *} p<0.001$. (c,d) The activation of various signaling pathways and HNF4 $\alpha$ expression were analyzed by Western blot in HepG2, HepG2.2.15, HepAD38, HepG2-pc, and HepG2-X. Inhibitors were treated as described in (b). (e) The expression levels of HNF4 $\alpha$, p-ERK, ERK, and HBx in HepG2-X and HepG2-pc cells were measured by Western blot following treatment with or without ERK inhibitor, U0126 $(10 \mu \mathrm{M})$. The data represent the results from three independent experiments.

The level of HNF $4 \alpha$ protein were measured in parallel. Suppression of HNF4 $\alpha$ was only restored by inhibiting the ERK signaling pathway in HepG2.2.15 (Figure 3c, left panel), and HepAD38 (Figure 3c, right panel). Successful suppression of each signaling pathway by the selected signal inhibitor was confirmed through measurement of the phosphorylated form of each target protein (p-ERK, p-AKT, $\mathrm{p}-\mathrm{JNK}$, and $\mathrm{p}$-P38). Moreover, the unphosphorylated form of target proteins were determined as a proof of activation of each signaling pathway in the two HBV stable cell lines (Figure 3c, right and left panels).

The activation of ERK was compared with the transiently expressed HBV and further confirmed in HepG2, HepG2-pc, and HepG2-X cells (Figure 3d). The p-ERK-dependent suppression of HNF4 $\alpha$ was only observed in stable cell lines. Moreover, the suppressed level of HNF4 $\alpha$ was recovered by inhibiting the ERK signaling pathway (U0126) in HepG2-X stable cells (Figure 3e). The inhibition of ERK was confirmed by measuring phosphorylated ERK. Therefore, these results suggest that HBx downregulates $\mathrm{HNF} 4 \alpha$ at the transcriptional level through the ERK signaling pathway.

\subsection{HNF4 $\alpha$ Expression Is Suppressed in Long-term Expression of HBV in Mice}

We then investigated whether the level of HNF4 $\alpha$ is also downregulated by HBV in vivo. Expression of HBV in mouse liver was done by in vivo transfection, as previously described [23]. The 6 weeks aged C57BL/6 mice were hydrodynamically injected with a number of plasmids harboring different HBV genotypes (A, B, and C) and the levels of HBeAg and HBsAg in mice serum were regularly measured up to six weeks post infection (Figure 4a). The relative level of $\mathrm{HBeAg}$ and HBsAg varied between the two mice infected with same genotype (A1, A2; B1, B2 and C1, C2) and among the mice infected with different $\mathrm{HBV}$ genotypes. Compared to mice injected with genotype A HBV, the levels of HBeAg and HBsAg lasted longer in mice infected with genotypes B and C. Particularly, in genotype A-infected mice, HBeAg level was lower than that of other genotypes and fell sharply up to the end point of infection course (six weeks) (Figure 4a). To compare the quantitative level of HBsAg between genotypes, the level of HBsAg in mice serum was quantified at one week post infection. In line with the data in Figure 4a, mice injected with pAAV HBV genotype B (B1 and B2), exhibited the highest HBsAg level at one-week post infection $(30 \mu \mathrm{g} / \mathrm{mL})$ whereas genotype A-infected mice (A1 and A2) showed the lowest HBsAg level $(10 \mu \mathrm{g} / \mathrm{mL})$ (Figure $4 \mathrm{~b})$.

Next, we analyzed the HNF4 $\alpha$ protein level in the mouse liver tissues. After one week of HBV infection, the level of HNF $4 \alpha$ remained constant among all the three HBV genotypes tested (Figure 4c). After 6 weeks of infection, however, the level of HNF4 $\alpha$ was strongly suppressed in the livers of all infected mice (Figure 4c, right). The levels of other nuclear factors were not changed during one to six weeks. At 6 weeks post infection, the level of HBx protein was undetectable in all HBV-infected mice by Western blot, implying that the effect of HBx in reduction of HNF4 $\alpha$ during long-term HBV infection is cumulative and long-lasting. (Figure 4c).

Considering that the suppression of HNF $4 \alpha$ was associated with the ERK signaling pathway in human hepatoma cell lines, we then investigated the level of activated ERK in mice tissues. Western blotting showed that after 6 weeks of HBV infection, p-ERK protein level was upregulated in most liver tissues compared to the controls, implying that the ERK pathway was activated in mouse liver tissue (Figure $4 \mathrm{~d}$ ). These results demonstrate that HBV also downregulates $\mathrm{HNF} 4 \alpha$ in long-term infection through ERK-dependent signaling pathway in vivo. 
(a)
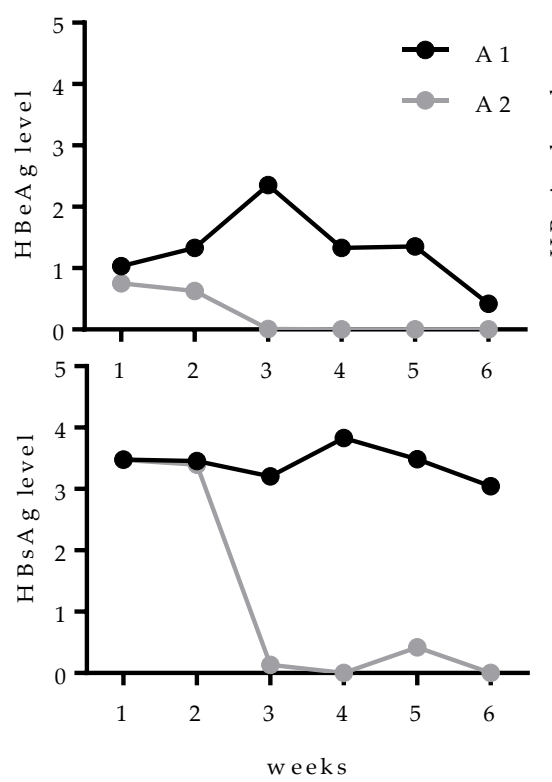

(b)

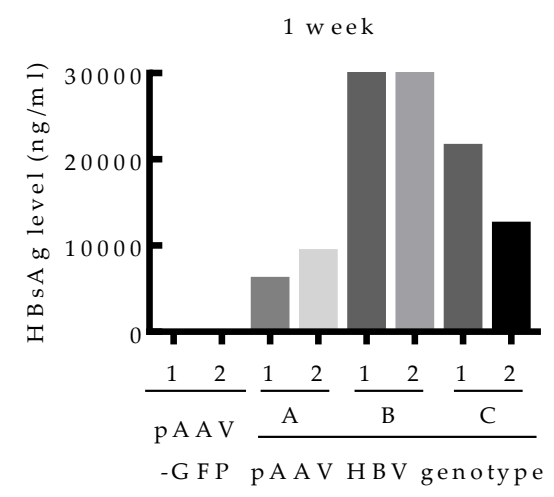

(c)
Genotype B
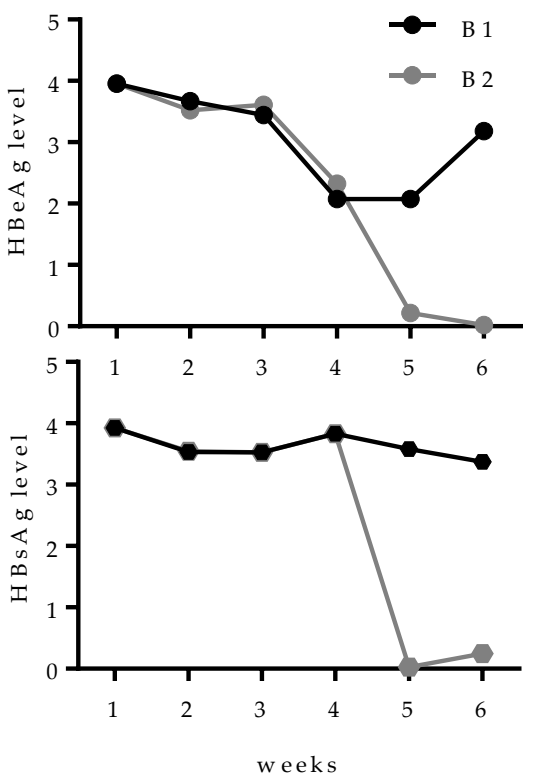

Genotype C
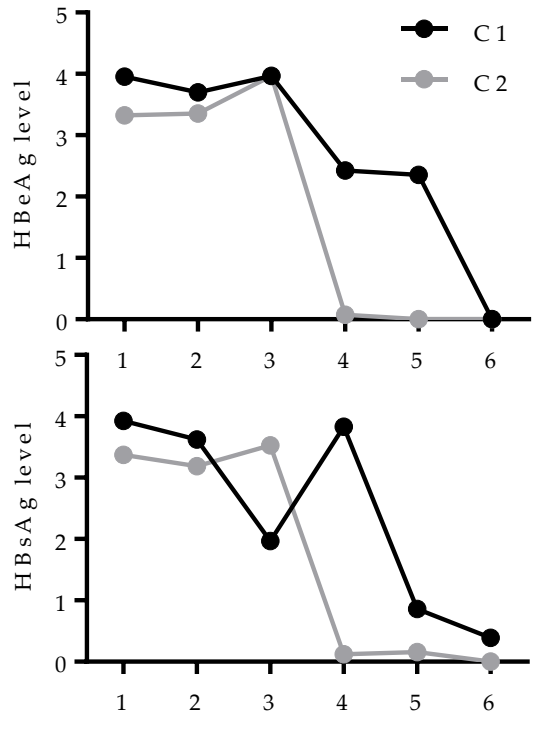

(d) 6 weeks

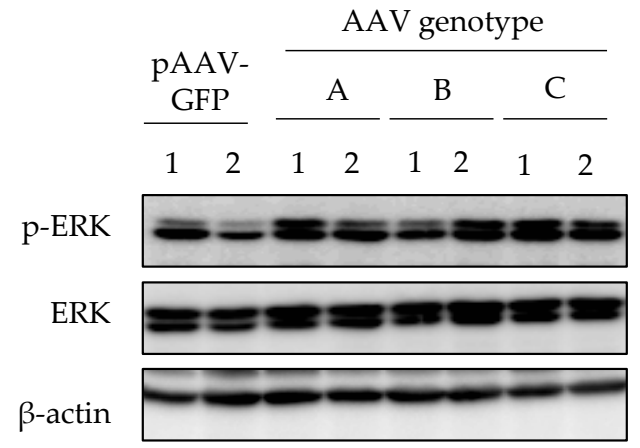

\section{1week}

pAAV- $\quad$ pAAV - HBVgenotype

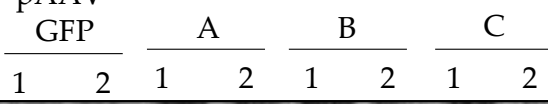

HNF $4 \alpha$

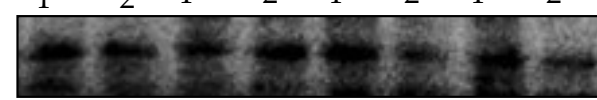

HNF1 $\alpha$

HNF3 $\beta$

C/EBPa
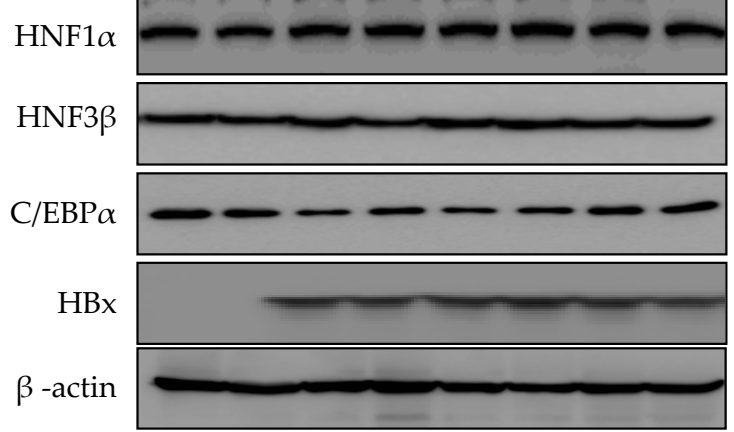

6 weeks

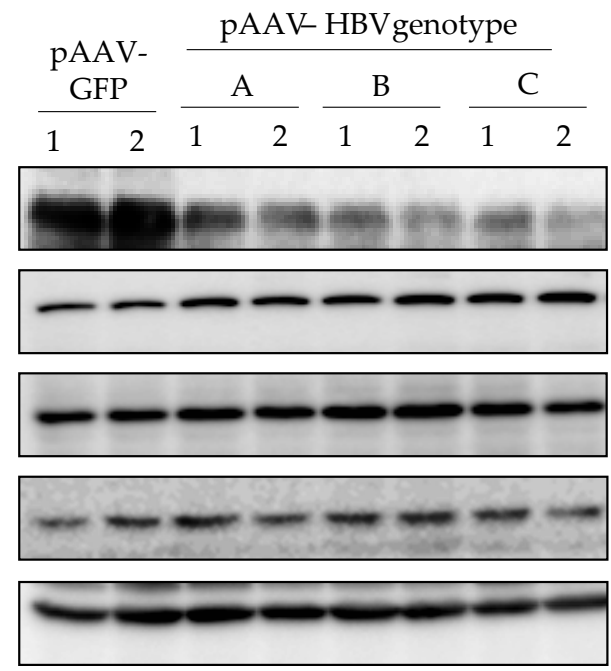


Figure 4. Long-term HBV infection suppressed HNF4 $\alpha$ expression in mice liver tissues. Plasmids for pAAV-GFP $(n=2)$ or pAAV-HBV $(n=6)$ (genotype A, B, or C) $(12.5 \mu \mathrm{g}$ each) were hydrodynamically injected in 6 weeks old C56BL/6 mice. (a) The relative level of HBsAg and HBeAg in mouse serum were measured weekly by ELISA. (b) At 1 week after hydrodynamic injection, the level of HBsAg in serum was quantified. (c) At 1 and 6 weeks after hydrodynamic injection with pAAV-GFP or pAAV-HBV (genotype A, B, or C), the level of indicated proteins in mouse livers were determined by Western blotting. (d) The activation of ERK was determined by Western blotting of phosphorylated ERK after 6 weeks of HBV expression.

\subsection{HNF4 $\alpha$ Expression Is Suppressed during Long-term HBV Infection in vitro and in vivo}

Based on the strong suppression of HNF4 $\alpha$ in mice expressing HBV, we further seek the effect of $\mathrm{HBV}$ infection on HNF4 $\alpha$ level using two different infection models. Initially, to determine the role of HBV infection on HNF4 $\alpha$, we performed long-term HBV infection in the HepG2-NTCP cell line which supports the full HBV life cycle [24] according to the experimental scheme in Figure ??a. An early, an intermediate and a late time point $(7,13$, and 31 days post infection (dpi), respectively) were selected to analyze the HNF4 $\alpha$ level. Successful HBV infection was confirmed by the measurement of $\mathrm{HBeAg}$ and HBsAg levels in cell culture supernatant (Figure ??b). Western blot data showed no difference between HNF4 $\alpha$ signal intensity in the presence or absence of HBV infection at 7 days post infection (dpi). However, significant reduction of $\mathrm{HNF} 4 \alpha$ protein level was observed at 13 dpi and the HNF4 $\alpha$ inhibitory effect of HBV infection was greater at the end of the infection course (31 dpi) (Figure ??c).

Lastly, HNF4 $\alpha$ level was explored in a long-term persistent HBV infection model in mice. Recombinant adeno-associated virus serotype 8 (rAAV)-HBV was intravenously delivered to the mice at two different titrations (Figure ??d). Infected mice were maintained up to 26 weeks post infection. The levels of HBeAg and HBsAg were regularly measured on a weekly basis (Figure ??e). rAAV8-GFP was used as a negative control. Expectedly, blood samples from mice infected with higher HBV titer displayed more HBeAg and HBsAg levels.

Persistent HBV infection remarkably attenuated the $\mathrm{HNF} 4 \alpha$ protein level in mice livers at 26 weeks post infection (Figure ??f). It seems that the suppressive effect of HBV was not dose-dependent as mice infected with different HBV titers manifested the same reduction level in HNF4 $\alpha$. Nonetheless, HBV core protein was mostly detectable at higher titer of rAAV-HBV. We further analyzed the level of HNF4 $\alpha$ in the liver biopsies of CHB patients (GSE83148) [25]. Compared to normal patients, the mRNA level of $\mathrm{HNF} 4 \alpha$ was significantly lower in CHB patients. These results obtained from long-term HBV infection models and public data suggest that persistent HBV infection downregulates HNF4 $\alpha$ in vivo. 
(a) HepG2-NTCP

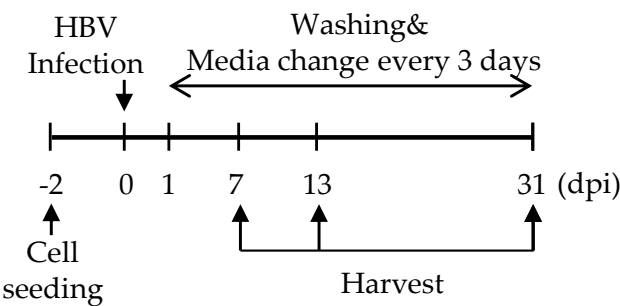

(c) HepG2-NTCP

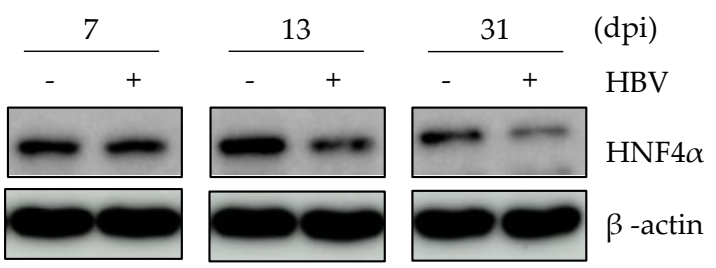

(e) (b)

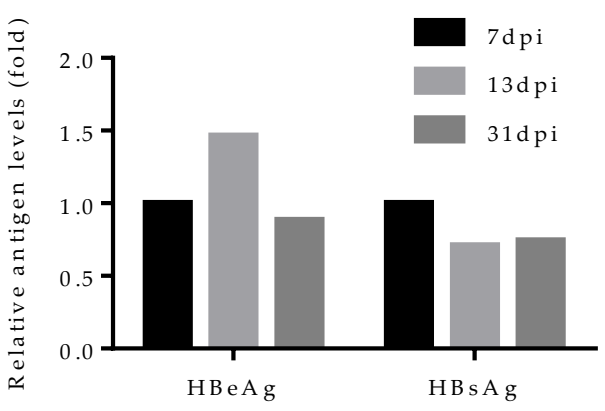

(d) rAAV-HBV (26 weeks)

ELISA ELISA (every 1week) (every 2weeks) ELISA

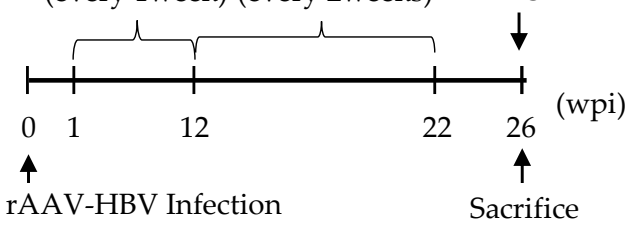

Route; IV $(150 \mu \mathrm{l})$

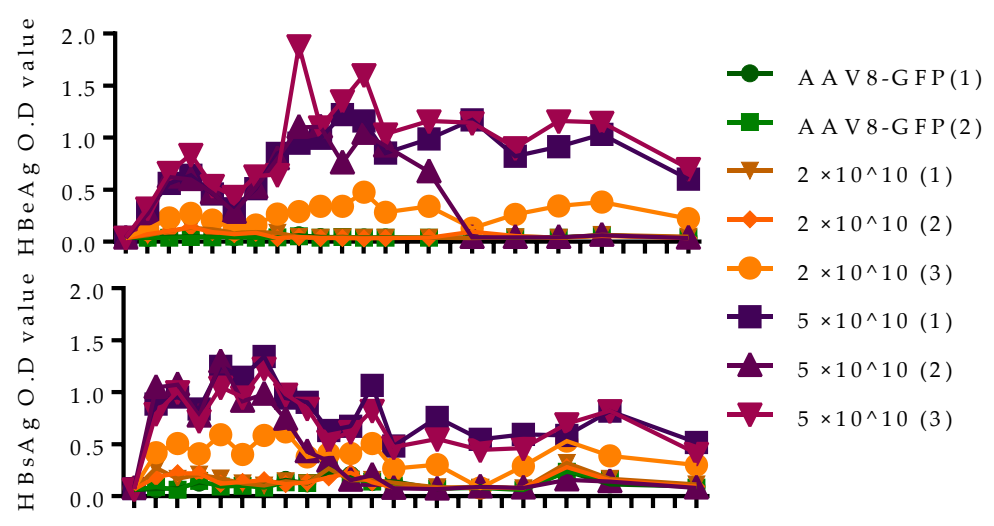

(g)

(f) 26 weeks
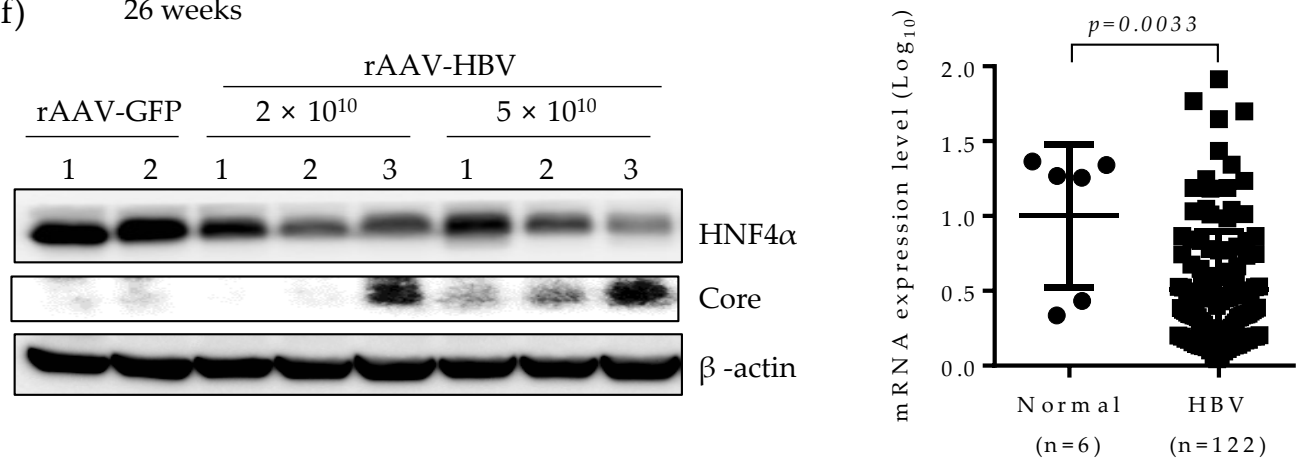

Figure 5. HNF4 $\alpha$ expression is suppressed following long-term HBV infection in vitro and in vivo mouse model. (a) HepG2-NTCP cells were infected with cell culture derived HBV at $2000 \mathrm{GEq} / \mathrm{cell}$. Cells were maintained in culture medium containing 2.5\% DMSO and were harvested at the indicated time points. (b) Secreted HBsAg and HBeAg were quantified by immunoassay. (c) HNF4 $\alpha$ protein level was analyzed by Western blotting. The data represent the results from three independent experiments. 
(d) Recombinant AAV-HBV (rAAV-HBV) $(n=6)$ at different titrations were injected intravenously (IV) (150 $\mu \mathrm{L}$ injection volume) into the tail vein of C57BL/6 mice. rAAV-GFP $(n=2)$ were injected into the tail vein of C57BL/6 mice. (e) Serum HBeAg and HBsAg levels from each infected mouse were quantified at indicated time points and plotted. (f) Expression levels of HNF4 $\alpha$ and HBV core protein in mouse liver tissues at 26 weeks post infection were determined by Western blotting. (g) Comparison of expression level of HNF4 $\alpha$ mRNA in liver biopsies between normal and CHB patients (GSE83148) obtained from public data. dpi, day post-infection; GEq, genomic equivalent.

\subsection{Suppression of HNF4 $\alpha$ Enhances Cell Proliferation in the Sustained Presence of HBV}

Studies have revealed that HNF4 $\alpha$ inhibits cell proliferation in hepatocytes and abolished HNF4a promotes tumor generation in the liver [25]. We, therefore, examined whether the suppressed HNF4 $\alpha$ by $\mathrm{HBx}$ really promotes cell proliferation in human hepatoma cell lines. As presented in Figure 6a (left), cell number doubled at six days following HBV induction (Tet off) in the HepAD38 cell line. In the HepG2.2.15 cell line, the number of cells increased by two-fold compare to parental HepG2 cell (Figure 6a middle). A similar pattern was observed in the HepG2-X cell line (Figure 6a right). These results suggest that the suppressed HNF $4 \alpha$ by HBx enhances cell proliferation.

We then examined cell proliferation by colony forming assay. Cells were seeded at $2 \times 10^{5}$ per well and incubated for 3 weeks. Consistently with the data obtained in Figure 6a, the number of colonies was increased by approximately two-fold in HepG2.2.15 and HepAD38 cell lines (Figure 6b,c). Cell proliferation was more dramatic in the HepG2-X cell line (three-fold increase) (Figure 6d).

Since the human hepatoma cell lines used in this study are a type of cancer cell lines, cells can grow in an anchorage-independent environment. To assess the effect of HBx-induced HNF4 $\alpha$ suppression on anchorage-independent growth, we examined colony formation by soft agar assay. Accordingly, cells were seeded at $1 \times 10^{4}$ per well and incubated for 4 weeks. Then, the colonies were stained for visualization. In the plate containing HBV expressing HepAD38 cells (no tetracycline), colony-forming efficiency increased by two-fold compared to the tetracycline treated control plate (Figure 6e). Likewise, colony-forming efficiency was doubled in HepG2-X cells as compared to vector-transfected control cells (Figure 6f). To further examine the direct effect of HNF4 $\alpha$ on the cell proliferation, HBV-expressing HepAD38 cells (Tet off) were transiently transfected with HNF4 $\alpha$ and were counted after four days. Compared with cell transfected with pc DNA, the number of cells transfected with HNF4 $\alpha$ was significantly decreased from $5.5 \times 10^{6}$ to $2.8 \times 10^{6}$ cells per well (Figure 6g).

In parallel the effect of HBV mediated $\mathrm{HNF} 4 \alpha$ downregulation on the cell proliferation was examine by a pharmacological approach. To do so, HBV-expressing HepAD38 cells were treated with U0126 (ERK inhibitor) at $20 \mu \mathrm{M}$ in another experimental set and the counted cell numbers were plotted in the bar graph (Figure $6 \mathrm{~g}$ ). The number of cells treated with the ERK inhibitor was decreased by 4.7-fold as compared to the DMSO treated cells. These results suggest that HBx enhances cell proliferation and colony formation in human hepatoma cells through the downregulation of $H N F 4 \alpha$. 

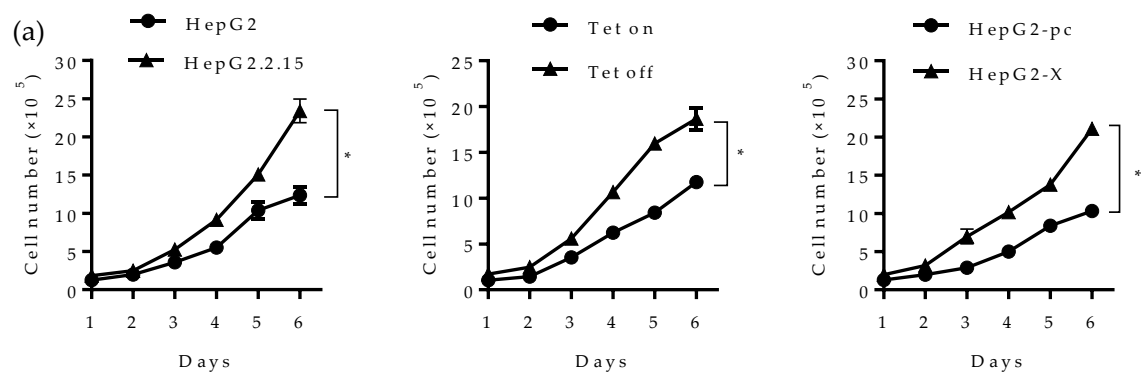

(b)

(c)

(d)
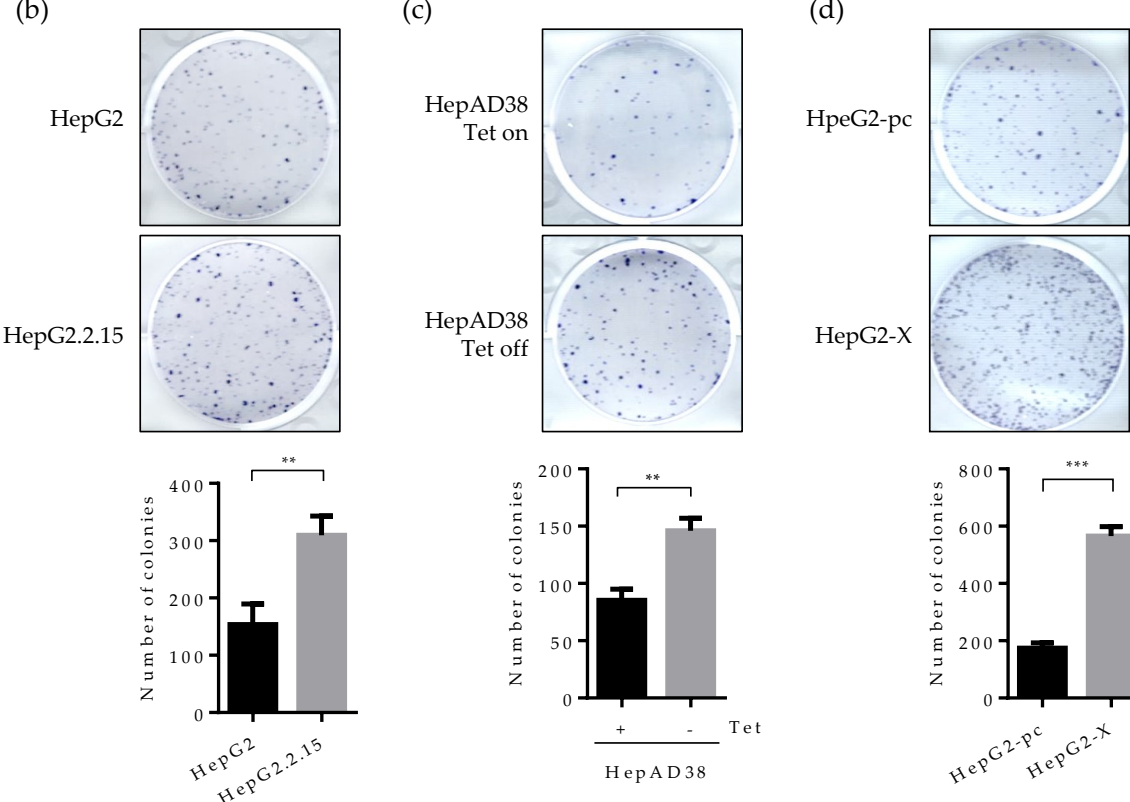

(e)

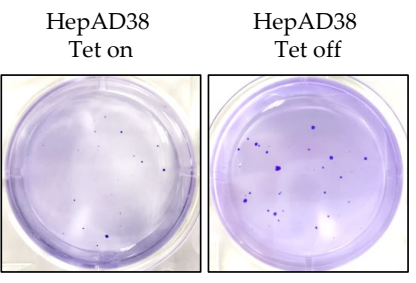

(f)
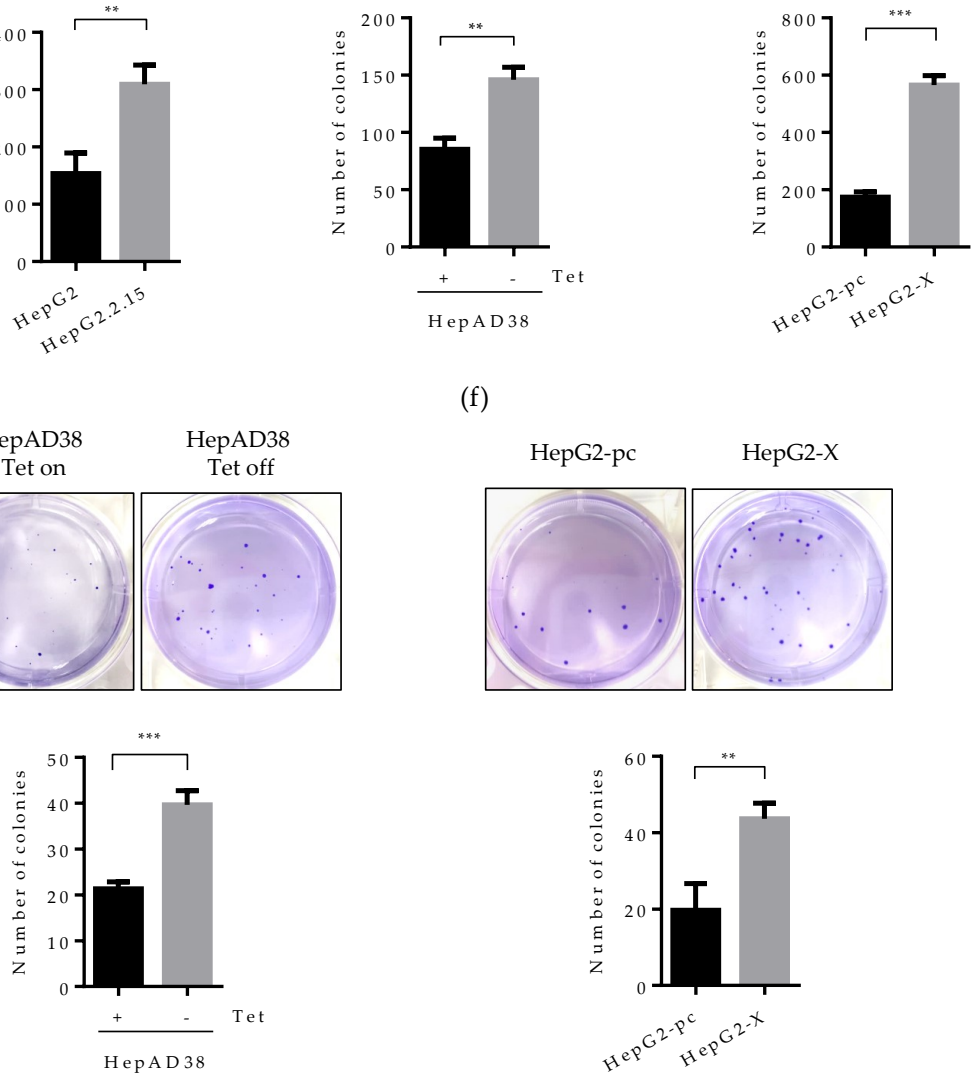

(g)
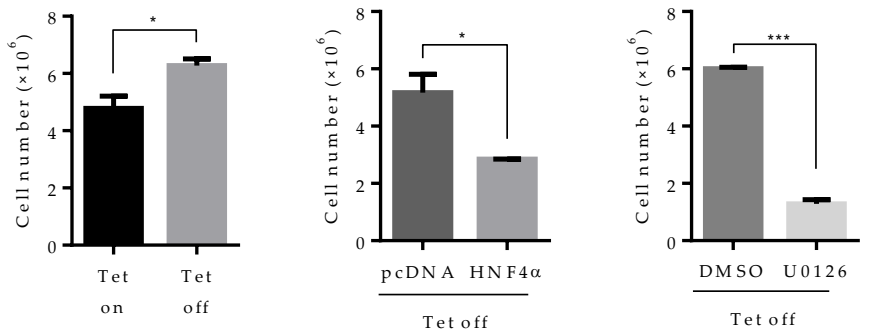
Figure 6. Effect of HBV-induced HNF4 $\alpha$ suppression on proliferation of hepatoma cells. (a) Cell proliferation assay was performed in human hepatoma cell lines. The indicated cells were seeded at a density of $2 \times 10^{5}$ per well and cultured for 6 days. Cell numbers were counted every day and plotted. (b-d) The indicated cells were seeded at 2000 cells/well (5000 cells/well for HepG2-pc and HepG2-X cells) and cultured for 4 weeks in complete medium to form colonies. Cell colonies were visualized with crystal violet staining. The number of colonies was counted and plotted. Tet on, with tetracycline; Tet off, without tetracycline. (e,f) Anchorage-independent cell growth was determined by soft agar assay. HepAD38 (with or without tetracycline) and HepG2 stable (HepG2-pc and HepG2-X) cells were incubated in soft agar plates for 4 weeks. Cells were then visualized by crystal violet staining. The colonies were counted and the data represent the means \pm SD of three independent experiments. ${ }^{* *} p<0.01$. (g) Cell proliferation assay in HepAD38 cell lines. A density of the cell was $2 \times 10^{5}$ per 12 -well and cultured for 6 days. Tetracycline was removed from indicated samples at the time of seeding. HNF $4 \alpha$ plasmid were transfected one day after Tet off. Moreover, the ERK inhibitor, U0126, was treated at a concentration of $20 \mu \mathrm{M}$ every day. Cells were counted at 4 days post transfection or inhibitor treatment. Cell numbers were analyzed and compared in a bar graph. The data represent the means of results from three independent experiments. ${ }^{*} p<0.05 ;{ }^{* *} p<0.001$. The statistical significances were performed by a Student's $t$-test.

\subsection{Effect of HBV-Induced Suppression of HNF4 $\alpha$ on Tumor Formation and Growth in Xenograft Mice}

To evaluate whether the downregulation of $\mathrm{HNF} 4 \alpha$ by HBV would affect the tumorigenicity of hepatoma cells in vivo, we investigated the tumor formation and growth in nude mice bearing HepAD38 or HepG2-X xenograft. HepAD38 cells grown in the presence or absence of tetracycline, were injected subcutaneously (SC) into each BALB/c nude mouse, respectively and the size of tumor was measured every 3 days. The mice injected with HepAD38 (grown with tetracycline) were housed with water containing $2 \mathrm{mg} / \mathrm{mL}$ tetracycline to suppress HBV expression and maintain the HNF4 $\alpha$ level. Up to 15 days after injection, there were no significant changes in the volume of tumor in mice bearing the HepAD38 xenograft. However, the volume of tumor in mouse injected with HepAD38 without tetracycline (HBV expression) increased gradually compared to the control mouse (no HBV expression) (Figure 7a). Mice were sacrificed 4 weeks after the SC injection and the volume and weight of tumor were examined. The weight and the volume of tumor were almost doubled in mice with HBV-expressing HepAD38 xenograft (without tetracycline) (Figure $7 \mathrm{~b}, \mathrm{c}$ ). The level of HNF $4 \alpha$ was dramatically suppressed in the mice bearing the HepAD38 xenograft maintained in the absence of tetracycline (Figure 7d), confirming the HBV-induced inhibition of HNF4 $\alpha$ in mice after 4 weeks of injection. Similar results were obtained with the HepG2-X xenograft (Figure 7e). The tumor volume was measured up to 39 days post SC injection. Between days 24 and 39, the tumor volume continuously expanded and tripled in size, reaching more than $600 \mathrm{~mm}^{2}$ and weighed $400 \mathrm{mg}$ at day 39 (Figure 7f,g). Furthermore, the level of HNF4 $\alpha$ was suppressed in HepG2-X xenografts in nude mice when measured at 5 weeks post injection, as compared to the mouse having a HepG2-pc xenograft (Figure 7h). These data also suggest that HBV infection downregulates HNF4 $\alpha$ and enhances tumorigenesis in vivo. 
(a)

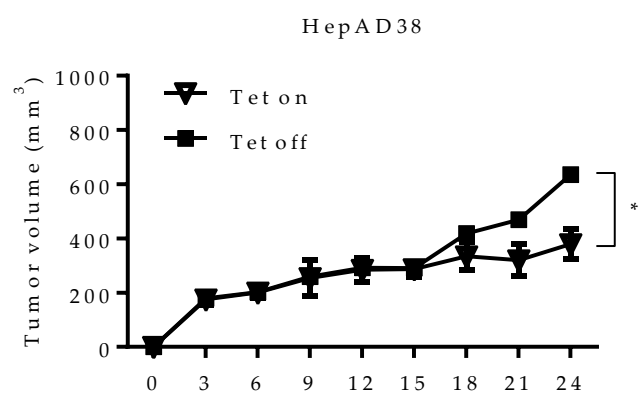

(c)

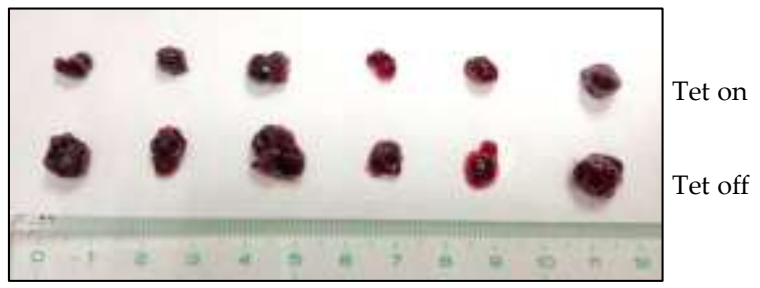

(e)

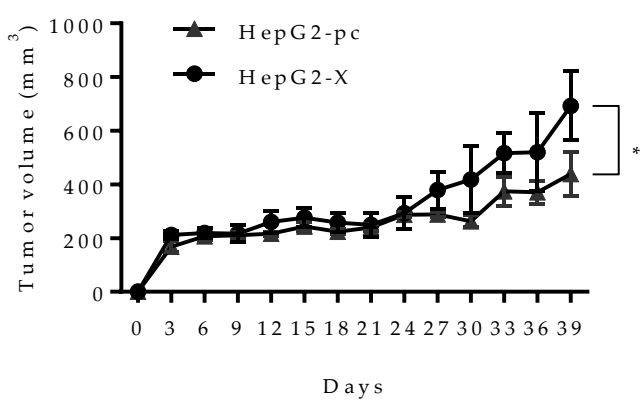

(g)

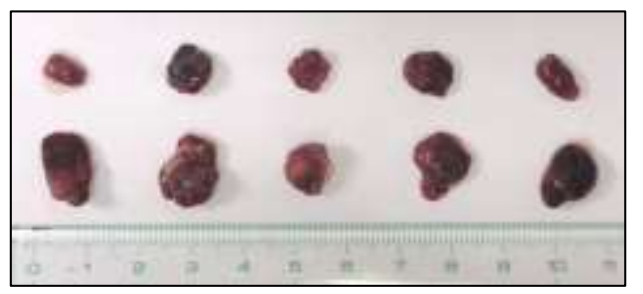

(b)

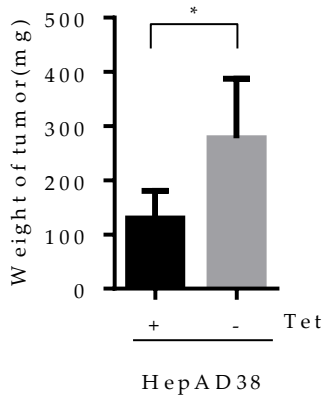

(d)

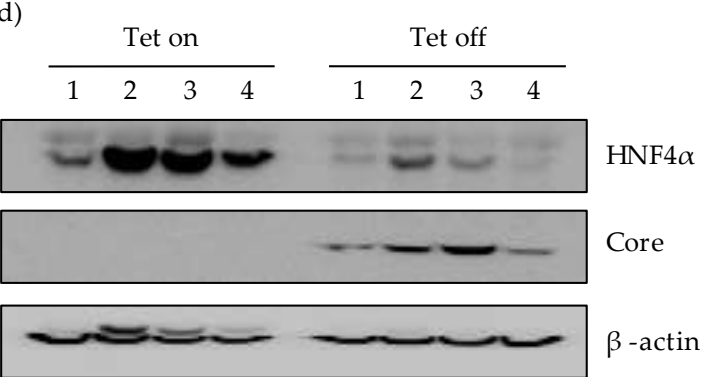

(f)

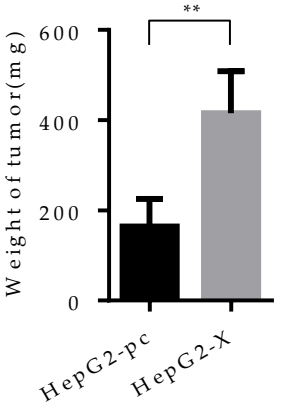

(h)

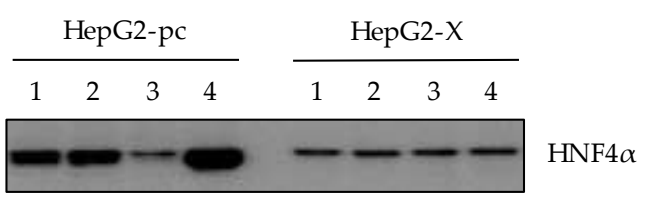

HepG2-X

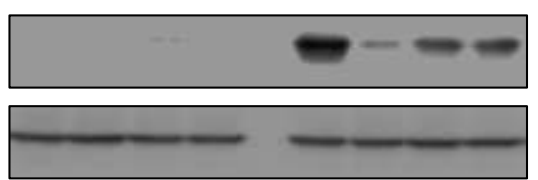

$\mathrm{HBx}$

Figure 7. Effect of HBV-induced HNF4 $\alpha$ suppression on tumor formation and growth in a xenograft mouse model. HepAD38 (a-d) or HepG2-X (e-h) cells $\left(1 \times 10^{7}\right)$ were mixed with Matrigel (1:1) and injected subcutaneously (SC) into the nude mice ( $n=5-6 /$ group). (a,e) The size of tumors bearing the indicated cells was measured every three days. The volume of the tumor was calculated and is shown in the growth curve. The Tet-on mice were housed with water containing $2 \mathrm{mg} / \mathrm{mL}$ tetracycline. Mice were sacrificed after 4 weeks. (b,f) Tumor weight after 4 weeks of injection were plotted. ${ }^{*} p<0.05$. $(\mathbf{c}, \mathbf{g})$ Pictures of xenografted tumors at 4 weeks following SC injection. (d,h) The expression levels of $\mathrm{HNF} 4 \alpha$ and $\mathrm{HBV}$ core/HBx protein in representative mouse livers were determined by Western blotting at 4 weeks post SC injection. 


\section{Discussion}

HNF4 $\alpha$ was identified as a nuclear factor which exists abundantly in the liver and controls the transcription of many genes involved in hepatocyte function $[9,11]$. Different roles of HNF4 $\alpha$ have been described, including the tumor suppressive ability that inhibits tumor progress in HCC [10,13,25].

$\mathrm{HBx}$ protein plays an important role in HBV replication and liver pathogenesis through regulation of different host proteins that are involved in cell differentiation and proliferation [6,26-30]. It has been reported that $\mathrm{HBx}$ modifies the epigenetic regulation of $\mathrm{HBV}$ by interaction with cccDNA, which serves as a template for HBV replication [31]. Therefore, it is crucial to unveil the exact mechanism of HBx-related carcinogenesis in order to inhibit HBV-related liver failure.

The inhibition of hepatocyte proliferation and tumor growth by HNF4 $\alpha$ have been well characterized in mice and human tissues [10]. Expectedly, HNF4 $\alpha$ suppression has been reported in cancers, including HCC $[13,25]$. Activation of AKT by the HBx protein downregulates HNF4 $\alpha$ transcription in rat hepatocyte and is suggested to contribute to the development of HBV-associated HCC $[14,32]$. In addition to the AKT signaling pathway, HBx can regulate ERK through the Notch1 pathway in HCC [14,20].

There has been no previous report on HBx-mediated downregulation of HNF4 $\alpha$ in human hepatoma cells. Moreover, the effect of other cell signaling pathways, including ERK on HBV-mediated HNF $4 \alpha$ suppression, have not been explored. Previous studies reported that serum from CHB patients enhanced cell growth and proliferation in HCC cells via the IGF-II/IGF-IR/MEK/ERK signaling pathway [33]. Moreover, HBx, through the activation of the ERK and p38 MAPK signaling pathways, promoted the metastasis of liver cancer [34]. Here, we showed that transcriptional regulation of HNF4 $\alpha$ is a target of HBx-mediated ERK activation in both human and mouse hepatocytes.

In this report, we demonstrated that HBV-induced downregulation of HNF4 $\alpha$ could enhance the proliferation of hepatoma cells and increase their tumorigenicity both in vitro and in vivo. Of note, HNF4a recovery through a pharmacological or genetical approach greatly contributed to the inhibition of cell proliferation. Moreover, our results clearly reveal the substantial efficacy of HBV expression on liver tumor progression in animal models. Therefore, HBV-mediated downregulation of HNF4a plays a considerable role in HBV-related carcinogenesis. Although others have shown that HBx activates signals that can diminish the overall level of HBV replication in order to balance cell survival [14], in long-term HBV infection, we showed a considerable reduction in HNF4 $\alpha$ level attained by HBx to elevate cell proliferation and tumor progress.

In the present study, by arresting several signaling pathways, we showed that the suppressed level of HNF $4 \alpha$ by HBV was only restored in the presence of U0126, an ERK signaling inhibitor. There was no alteration in the level of HNF4 $\alpha$ when inhibitors for AKT, JNK, p38 and mTOR were applied. Unlike the previous report, which suggested that the AKT signaling pathway is associated with the downregulation of HNF4 $\alpha$ in rat primary hepatocyte [14], our results here reveal that the suppression of HNF4 $\alpha$ during long-term HBV infection is associated with the ERK signaling pathway in human hepatoma cell lines and mouse models. Similarly to HBV genome expression, ectopic expression of HBx itself could induce the same diminishing effect on HNF4 $\alpha$ in the HepG2 cell. Notably, inhibiting the ERK signaling pathway restored HNF4 $\alpha$ protein level in the HepG2-X cell line.

We also evaluated the effect of different HBV genotypes on HNF4 $\alpha$ level in vivo. The expression level of HNF4 $\alpha$ was suppressed in long-term infection of HBV in the mouse model. Importantly, in mice infected with HBV genotype A, B or C, regardless of genotype variation, the HNF4 $\alpha$ level was plunged at six weeks post infection. In this study, even though the HNF1 $\alpha$ level was slightly decreased in HepG2.2.15 and HepAD38 cells as a result of HNF4 $\alpha$ reduction, there were no significant alteration in the HNF1 $\alpha$ level in mice data (Figure 4c). Further study is required to understand the exact correlation between HNF4 $\alpha$ and $\mathrm{HNF} 1 \alpha$ in mice infected with $\mathrm{HBV}$ in the long term.

Many findings implicate HBV infection as a major risk factor in the development of HCC [33,35]. Here, we demonstrated that prolonged HBV infection in susceptible host cell line (HepG2-NTCP) or in long-term infected mice can suppress the expression of anti-tumor $\mathrm{HNF} 4 \alpha$, particularly at later 
time points. This notion is in line with the fact that HCC occurs with a slow pace in HBV-infected patients and virus-induced tumorigenesis is mostly observed at late stages of infection [3,36,37]. Perhaps epigenetic modifications in HNF4 $\alpha$ suppressed cells during long-term HBV infection may contribute to liver carcinogenesis.

Overall, the results of our study with cultured human hepatocytes and in vivo mouse models demonstrate that $\mathrm{HBx}$ activation of the ERK1/2 signaling pathway downregulates HNF4 $\alpha$ and consequently contributes to the tumorigenesis in HBV infected liver.

\section{Materials and Methods}

\subsection{Cell Culture}

Human hepatoma cell lines (HepG2, HepG2.2.15, HepAD38, HepG2-pc, HepG2-X and HepG2-NTCP-K7) were grown in Dulbecco's Modified Eagle's medium (DMEM) containing $10 \%$ heat inactivated Fetal Bovine Serum (Capricorn; Ebsdorfergrund, Germany) and 1\% of penicillin-streptomycin (Gibco; BRL, Grand Island, NY, USA) at $37^{\circ} \mathrm{C}$ in $5 \% \mathrm{CO}_{2}$. The HepG2-NTCP-K7 cell line was kindly provided by Professor Ulrike Protzer (Institute of Virology, Munich, Germany).

\subsection{Plasmid Construction}

The constructs for WT HBV 1.2mer (1.2(+)), X-null HBV 1.2mer (1.2(-)), HBV 1.3mer (1.3(+)) and X-null HBV 1.3mer (1.3(-)) were kindly provided by Wang Shick Ryu [38,39] (Yonsei University, Seoul, South Korea). The construct of HBx-HA was described in a previous study [28]. The plasmids for pAAV control vector and pAAV-HBV genotype A, B, and C were kindly provided by Professor Pei-Jer Chen (National Taiwan University, Taipei, Taiwan) [40]. In order to make HNF4 $\alpha$ expressing construct, the full sequence of HNF4 $\alpha$ was cloned into the pcDNA3.1(+) vector (Invitrogen, CA, USA).

\subsection{Animal Experiment}

Hydrodynamic liver transfection of pAAV vector and pAAV-HBV were performed in C57B/L6 mice ( 6 weeks old) with transfection of $12.5 \mu \mathrm{g}$ of plasmids. The plasmid DNA was injected into the tail vein with high pressure within 3-6 s. The mice were sacrificed after 1 week or 6 weeks of DNA injection. Recombinant AAV-HBV construct (rAAV-HBV) expressing AAV8 serotype was prepared from pAAV-HBV plasmid and was injected into the mice through intravenous injection (IV). All animal experiments were conducted with the approval of Institutional Animal Care and US Committee (IACUC), Konkuk University (KU15049, 27th April 2015).

\subsection{Transfection and Reagents}

Transient transfection was performed at $70-80 \%$ of cell confluency, using Lipofectamine 2000 reagent (Invitrogen, Carlsbad, CA, USA) according to the manufacturer's instruction manual. The cells were harvested 2 days after transfection.

Signaling pathway inhibitor molecules, U0126, LY294002, SP600125, SB203580, Rapamycin were purchased from Cell Signaling Technology, (Danvers, MA, USA). The U0126, LY294002, and SP600125 were treated at $10 \mu \mathrm{M}, \mathrm{SB} 203580$ was treated at $20 \mu \mathrm{M}$, and rapamycin was treated at $100 \mathrm{mM}$, respectively.

\subsection{Virus Particle Production}

For HBV particle production, HepAD38 cells were cultured in large scale with media containing tetracycline $(500 \mathrm{ng} / \mathrm{mL})$ as described previously [41]. Cells were transferred to a 5-layer T175 flask in tetracycline free media for 2 weeks to induce virus expression. Subsequently, the supernatant was collected every three days, centrifuged at $6000 \mathrm{rpm}$ and filtered using $0.22 \mu \mathrm{m}$ pore size filters. Virus particles in the collected supernatant were concentrated overnight at $4{ }^{\circ} \mathrm{C}$ using $6.5 \%$ PEG 8000 . 
Concentrated supernatant was centrifuged for $1 \mathrm{~h}$ at 10,000 rpm. Pellet was resuspended in $10 \%$ FBS/PBS. Virus titration was quantified by dot blot assay.

\subsection{Virus Infection}

HepG2-NTCP-K7 cells were seeded in 6-well collagen coated plates. HBV infection was performed using cell culture derived inoculum about $2000 \mathrm{Geq} / \mathrm{cell}$ per well in a mixture with culture media containing 4\% PEG 8000 for $16 \mathrm{~h}$. Cells were washed extensively with PBS. Infected cells were maintained in the media with $2.5 \%$ DMSO and harvested as indicated time points.

\subsection{Western Blot}

The harvested cells and obtained tissues were lysed by RIPA buffer [20 mM Tris/HCl, 1\% NP-40, 0.5\% phosphatase inhibitor cocktail (Sigma, St Luis, MO, USA), $150 \mathrm{mM} \mathrm{NaCl}, 2 \mathrm{mM} \mathrm{KCl}, \mathrm{pH} 7.4]$. The debris was removed by centrifuging at 12000 RPM for $20 \mathrm{~min}$. After the filtering of cell debris, levels of protein in the lysate were quantified by a BCA protein assay kit (Thermo Fisher scientific, Waltham, MA, USA). The samples were mixed with 5X SDS sample buffer and boiled at $95^{\circ} \mathrm{C}$ for $4 \mathrm{~min}$. The proteins were separated by SDS-PAGE and transferred to polyvinylidene fluoride (PVDF) membrane (Millipore, Burlington, MA, USA). The transferred membranes were washed with TBS-T. Antibodies were used in 1:2000 ratios. The primary antibodies used were as follows: anti-HNF4 $\alpha$ (Santa Cruz, CA, USA), anti-HNF1 $\alpha$ (Santa Cruz), anti-HNF3 $\beta$ (Santa Cruz), anti-C/EBP $\alpha$ (Santa Cruz), anti-HBcAg (Dako, Glostrup, Denmark), anti-HBx protein (Abcam, UK), anti-p-ERK (Cell Signaling Technology, MA), anti-ERK (Cell Signaling Technology), anti-p-AKT (Cell Signaling Technology), anti-AKT (Cell Signaling Technology), anti-p-JNK (Cell Signaling Technology), anti-JNK (Cell Signaling Technology), anti-p-p38 (Cell Signaling Technology), anti-p38 (Cell Signaling Technology), anti- $\beta$-actin (Sigma-Aldrich Co, St Louis, MO, USA).

\subsection{ELISA}

The levels of HBeAg and HBsAg were examined with the ELISA kit (Wantai, Beijing, China) according to the manufacturer's instructions. For HBeAg and HBsAg measurement, samples were diluted at a 1:10 or 1:100 ratio, respectively. The absorbance values were measured at $450 \mathrm{~nm}$ via a microplate reader.

\subsection{Real-time Quantitative PCR ( $q R T-P C R)$}

HepG2, HepG2.2.15, HepAD38 cells were lysed with Trizol reagent (Sigma) according to the manufacturer's manual. An amount of $2 \mu \mathrm{g}$ of extracted total RNA was used for the reverse transcription reaction by MMLV reverse transcriptase (Intron Biotechnology, Kyeonggi, Korea) in a final volume of 20 microliter. qRT-PCR was carried out to amplify cDNA by using SYBR Green PCR master mix (Applied Biosystems) in an ABI PRISM 7500 sequence detection machine.

Relative quantification was performed by the comparative $\Delta \Delta \mathrm{Ct}$ method [42]. The results were shown as an $n$-fold difference to calibrator $\left(\mathrm{RQ}=2^{-\Delta \Delta C t}\right)$. The HNF4 $\alpha$ gene was amplified using targeting primers; For 5' -GAGTGGGCCAAGTACATCCCAG-3', Rev 5'-GCTTTGAGGTAGGCATACT-3'

\subsection{Cell Proliferation and Colony-Forming Assay}

For cell proliferation assay, cells were seeded at $2 \times 10^{5}$ cells per well in a 6-well plate or 12-well plate. The number of cells in each well was determined by cell counting using a hemocytometer. Colony forming assay was performed to compare the colony forming abilities of each cell line. Cells were harvested with trypsin-EDTA and resuspended in a singular form. The $1 \times 10^{4}$ cells were plated in a 6-well plate. After incubation for 4 weeks, colonies were stained with $0.5 \%$ crystal violet (Sigma) for $30 \mathrm{~min}$ at room temperature. 


\subsection{Soft Agar Assay}

To determine anchorage-independent growth of each cell lines, soft agar assay was performed. Cells $\left(1.0 \times 10^{4}\right.$ cells per well) mixed with $0.35 \%$ Difco Noble Agar (BD) in complete medium were plated on the top of $0.5 \%$ agar layer in a 6-well plate with complete medium. Growth medium $(1.5 \mathrm{~mL})$ was added on the top of the layer and the cells were incubated at $37^{\circ} \mathrm{C}$ for 4 weeks. For visualization, foci were stained with $0.0005 \%$ crystal violet.

\subsection{Xenograft}

HepAD38 (maintained with or without tetracycline) or HepG2-X cell lines were injected into the six-week old male BALB/c nude mice (Nara Biotec, Seoul, Korea). Cells were counted at 1 $\times 10^{7}$ in a volume of $100 \mu \mathrm{L}$ with 1:1 of Matrigel (Corning, NY, USA) and subcutaneously (SC) inoculated into the back of the mice. Mice xenografted with HepAD38 grown with tetracycline were housed with water containing $2 \mathrm{mg} / \mathrm{mL}$ tetracycline. The size of tumor was measured every 3 days using a caliper. The tumor volume was calculated by the following equation: tumor volume $\left[\mathrm{mm}^{3}\right]=($ length $[\mathrm{mm}]) \times(\text { width }[\mathrm{mm}])^{2} \times 0.52$. All the measurements were compared using the Student's t-test. The animal procedures were approved by the Animal Care Committee at Konkuk University (KU15049, 27th April 2015).

Author Contributions: S.P. and Y.N.H. performed the study, acquisition and analysis of data, and drafted the manuscript. M.D. contributed to data analysis and writing the manuscript. A.R.L., E.-S.P., Y.K.P., J.W., N.Y.K., S.Y.C., J.J.S., and C.H.A. provided technical assistance. K.-H.K. supervised the study and participated in the experimental design, data analysis, and paper writing. All authors have read and agreed to the published version of the manuscript.

Funding: This study was supported by Konkuk University in 2019.

Conflicts of Interest: The authors declare no conflict of interest.

\section{Abbreviations}

$\begin{array}{ll}\text { CHB } & \text { Chronic Hepatitis B Virus } \\ \text { dpi } & \text { Days post infection } \\ \text { Geq } & \text { Genome equivalent } \\ \text { HBeAg } & \text { HBV e antigen } \\ \text { HBsAg } & \text { HBV surface antigen } \\ \text { HBV } & \text { Hepatitis B virus } \\ \text { HBx } & \text { Hepatitis B virus X protein } \\ \text { HCC } & \text { Hepatocellular carcinoma } \\ \text { HNF1 } \alpha & \text { Hepatocyte nuclear factor } 1 \alpha \\ \text { HNF3 } \beta & \text { Hepatocyte nuclear factor } 3 \text { beta } \\ \text { HNF4 } \alpha & \text { Hepatocyte nuclear factor } 4 \alpha \\ \text { IV } & \text { Intravenous } \\ \text { NTCP } & \text { Sodium-taurocholate cotransporting polypeptide } \\ \text { pAAV-HBV } & \text { Plasmid adeno associated virus-hepatitis B virus } \\ \text { rAAV-HBV } & \text { Recombinant adeno associated virus-hepatitis B virus } \\ \text { SC } & \text { Subcutaneous } \\ \text { Tet } & \text { Tetracycline } \\ \text { wpi } & \text { Weeks post infection }\end{array}$

\section{References}

1. Ganem, D.; Prince, A.M. Hepatitis B virus infection-natural history and clinical consequences. N. Engl. J. Med. 2004, 350, 1118-1129. [CrossRef] [PubMed]

2. Torre, L.A.; Bray, F.; Siegel, R.L.; Ferlay, J.; Lortet-Tieulent, J.; Jemal, A. Global cancer statistics, 2012. Ca: A Cancer J. Clin. 2015, 65, 87-108. [CrossRef] [PubMed] 
3. Centers for Disease Control and Prevention (CDC). Hepatocellular carcinoma-United States, 2001-2006. MMWR 2010, 59, 517-520.

4. Seeger, C.; Mason, W.S. Hepatitis B virus biology. Microbiol. Mol. Biol. Rev. 2000, 64, 51-68. [CrossRef]

5. De Meyer, S.; Gong, Z.J.; Suwandhi, W.; van Pelt, J.; Soumillion, A.; Yap, S.H. Organ and species specificity of hepatitis B virus (HBV) infection: A review of literature with a special reference to preferential attachment of HBV to human hepatocytes. J. Viral Hepat. 1997, 4, 145-153. [CrossRef] [PubMed]

6. Tang, H.; Delgermaa, L.; Huang, F.; Oishi, N.; Liu, L.; He, F.; Zhao, L.; Murakami, S. The transcriptional transactivation function of HBx protein is important for its augmentation role in hepatitis B virus replication. J. Virol. 2005, 79, 5548-5556. [CrossRef] [PubMed]

7. Brechot, C.; Kremsdorf, D.; Soussan, P.; Pineau, P.; Dejean, A.; Paterlini-Brechot, P.; Tiollais, P. Hepatitis B virus (HBV)-related hepatocellular carcinoma (HCC): Molecular mechanisms and novel paradigms. Pathol. Biol. 2010, 58, 278-287. [CrossRef] [PubMed]

8. Ng, S.A.; Lee, C. Hepatitis B virus X gene and hepatocarcinogenesis. J. Gastroenterol. 2011, 46, $974-990$. [CrossRef]

9. Hayhurst, G.P.; Lee, Y.H.; Lambert, G.; Ward, J.M.; Gonzalez, F.J. Hepatocyte nuclear factor $4 \alpha$ (nuclear receptor 2A1) is essential for maintenance of hepatic gene expression and lipid homeostasis. Mol. Cell. Biol. 2001, 21, 1393-1403. [CrossRef]

10. Bonzo, J.A.; Ferry, C.H.; Matsubara, T.; Kim, J.H.; Gonzalez, F.J. Suppression of hepatocyte proliferation by hepatocyte nuclear factor $4 \alpha$ in adult mice. J. Biol. Chem. 2012, 287, 7345-7356. [CrossRef]

11. Parviz, F.; Matullo, C.; Garrison, W.D.; Savatski, L.; Adamson, J.W.; Ning, G.; Kaestner, K.H.; Rossi, J.M.; Zaret, K.S.; Duncan, S.A. Hepatocyte nuclear factor $4 \alpha$ controls the development of a hepatic epithelium and liver morphogenesis. Nat. Genet. 2003, 34, 292-296. [CrossRef] [PubMed]

12. Battle, M.A.; Konopka, G.; Parviz, F.; Gaggl, A.L.; Yang, C.; Sladek, F.M.; Duncan, S.A. Hepatocyte nuclear factor $4 \alpha$ orchestrates expression of cell adhesion proteins during the epithelial transformation of the developing liver. Proc. Natl. Acad. Sci. USA 2006, 103, 8419-8424. [CrossRef] [PubMed]

13. Tanaka, T.; Jiang, S.; Hotta, H.; Takano, K.; Iwanari, H.; Sumi, K.; Daigo, K.; Ohashi, R.; Sugai, M.; Ikegame, C.; et al. Dysregulated expression of P1 and P2 promoter-driven hepatocyte nuclear factor- $4 \alpha$ in the pathogenesis of human cancer. J. Pathol. 2006, 208, 662-672. [CrossRef] [PubMed]

14. Rawat, S.; Bouchard, M.J. The hepatitis B virus (HBV) HBx protein activates AKT to simultaneously regulate HBV replication and hepatocyte survival. J. Virol. 2015, 89, 999-1012. [CrossRef]

15. Liu, H.; Lou, G.; Li, C.; Wang, X.; Cederbaum, A.I.; Gan, L.; Xie, B. HBx inhibits CYP2E1 gene expression via downregulating HNF4 $\alpha$ in human hepatoma cells. PLoS ONE 2014, 9, e107913. [CrossRef]

16. Chen, E.Q.; Sun, H.; Feng, P.; Gong, D.Y.; Liu, C.; Bai, L.; Yang, W.B.; Lei, X.Z.; Chen, L.Y.; Huang, F.J.; et al. Study of the expression levels of Hepatocyte nuclear factor $4 \alpha$ and 3 beta in patients with different outcome of HBV infection. Virol. J. 2012, 9, 23. [CrossRef]

17. Villanueva, A.; Newell, P.; Chiang, D.Y.; Friedman, S.L.; Llovet, J.M. Genomics and signaling pathways in hepatocellular carcinoma. Semin. Liver Dis. 2007, 27, 55-76. [CrossRef]

18. Llovet, J.M.; Ricci, S.; Mazzaferro, V.; Hilgard, P.; Gane, E.; Blanc, J.F.; de Oliveira, A.C.; Santoro, A.; Raoul, J.L.; Forner, A.; et al. Sorafenib in advanced hepatocellular carcinoma. N. Engl. J. Med. 2008, 359, 378-390. [CrossRef]

19. Yu, P.; Ye, L.; Wang, H.; Du, G.; Zhang, J.; Zhang, J.; Tian, J. NSK-01105 inhibits proliferation and induces apoptosis of prostate cancer cells by blocking the Raf/MEK/ERK and PI3K/Akt/mTOR signal pathways. Tumour Biol. 2015, 36, 2143-2153. [CrossRef]

20. Liao, B.; Zhou, H.; Liang, H.; Li, C. Regulation of ERK and AKT pathways by hepatitis B virus X protein via the Notch1 pathway in hepatocellular carcinoma. Int. J. Oncol. 2017, 51, 1449-1459. [CrossRef]

21. Henkler, F.; Lopes, A.R.; Jones, M.; Koshy, R. Erk-independent partial activation of AP-1 sites by the hepatitis B virus HBx protein. J. Gen. Virol. 1998, 79, 2737-2742. [CrossRef] [PubMed]

22. Nijhara, R.; Jana, S.S.; Goswami, S.K.; Rana, A.; Majumdar, S.S.; Kumar, V.; Sarkar, D.P. Sustained activation of mitogen-activated protein kinases and activator protein 1 by the hepatitis $\mathrm{B}$ virus $\mathrm{X}$ protein in mouse hepatocytes in vivo. J. Virol. 2001, 75, 10348-10358. [CrossRef] [PubMed]

23. Kim, D.H.; Park, E.S.; Lee, A.R.; Park, S.; Park, Y.K.; Ahn, S.H.; Kang, H.S.; Won, J.H.; Ha, Y.N.; Jae, B.; et al. Intracellular interleukin-32gamma mediates antiviral activity of cytokines against hepatitis $B$ virus. Nat. Commun. 2018, 9, 3284. [CrossRef] [PubMed] 
24. Ko, C.; Chakraborty, A.; Chou, W.M.; Hasreiter, J.; Wettengel, J.M.; Stadler, D.; Bester, R.; Asen, T.; Zhang, K.; Wisskirchen, K.; et al. Hepatitis B virus genome recycling and de novo secondary infection events maintain stable cccDNA levels. J. Hepatol. 2018, 69, 1231-1241. [CrossRef]

25. Walesky, C.; Apte, U. Role of hepatocyte nuclear factor $4 \alpha(\mathrm{HNF} 4 \alpha)$ in cell proliferation and cancer. Gene Expr. 2015, 16, 101-108. [CrossRef]

26. Ali, A.; Abdel-Hafiz, H.; Suhail, M.; Al-Mars, A.; Zakaria, M.K.; Fatima, K.; Ahmad, S.; Azhar, E.; Chaudhary, A.; Qadri, I. Hepatitis B virus, HBx mutants and their role in hepatocellular carcinoma. World J. Gastroenterol. 2014, 20, 10238-10248. [CrossRef]

27. Bouchard, M.J.; Wang, L.H.; Schneider, R.J. Calcium signaling by HBx protein in hepatitis B virus DNA replication. Science 2001, 294, 2376-2378. [CrossRef]

28. Lee, A.R.; Lim, K.H.; Park, E.S.; Kim, D.H.; Park, Y.K.; Park, S.; Kim, D.S.; Shin, G.C.; Kang, H.S.; Won, J.; et al. Multiple Functions of Cellular FLIP Are Essential for Replication of Hepatitis B Virus. J. Virol. 2018, 92, e00339-18. [CrossRef]

29. Slagle, B.L.; Bouchard, M.J. Hepatitis B Virus X and Regulation of Viral Gene Expression. Cold Spring Harb. Perspect. Med. 2016, 6, a021402. [CrossRef]

30. Slagle, B.L.; Bouchard, M.J. Role of HBx in hepatitis B virus persistence and its therapeutic implications. Curr. Opin. Virol. 2018, 30, 32-38. [CrossRef]

31. Belloni, L.; Pollicino, T.; De Nicola, F.; Guerrieri, F.; Raffa, G.; Fanciulli, M.; Raimondo, G.; Levrero, M. Nuclear HBx binds the HBV minichromosome and modifies the epigenetic regulation of cccDNA function. Proc. Natl. Acad. Sci. USA 2009, 106, 19975-19979. [CrossRef] [PubMed]

32. Zeng, X.; Lin, Y.; Yin, C.; Zhang, X.; Ning, B.F.; Zhang, Q.; Zhang, J.P.; Qiu, L.; Qin, X.R.; Chen, Y.X.; et al. Recombinant adenovirus carrying the hepatocyte nuclear factor- $1 \alpha$ gene inhibits hepatocellular carcinoma xenograft growth in mice. Hepatology 2011, 54, 2036-2047. [CrossRef] [PubMed]

33. Ji, Y.; Wang, Z.; Chen, H.; Zhang, L.; Zhuo, F.; Yang, Q. Serum from Chronic Hepatitis B Patients Promotes Growth and Proliferation via the IGF-II/IGF-IR/MEK/ERK Signaling Pathway in Hepatocellular Carcinoma Cells. Cell. Physiol. Biochem. 2018, 47, 39-53. [CrossRef] [PubMed]

34. Tu, W.; Gong, J.; Tian, D.; Wang, Z. Hepatitis B Virus X Protein Induces SATB1 Expression through Activation of ERK and p38MAPK Pathways to Suppress Anoikis. Dig. Dis. Sci. 2019, 64, 3203-3214. [CrossRef] [PubMed]

35. Farazi, P.A.; DePinho, R.A. Hepatocellular carcinoma pathogenesis: From genes to environment. Nature reviews. Cancer 2006, 6, 674-687. [PubMed]

36. Yan, S.Y.; Fan, J.G.; Qio, L. Hepatitis B Virus (HBV) Infection and Hepatocellular Carcinoma- New Insights for an Old Topic. Curr. Cancer Drug Targets 2017, 17, 505-511. [CrossRef] [PubMed]

37. Rawla, P.; Sunkara, T.; Muralidharan, P.; Raj, J.P. Update in global trends and aetiology of hepatocellular carcinoma. Contemp. Oncol. 2018, 22, 141-150. [CrossRef]

38. Ko, C.; Lee, S.; Windisch, M.P.; Ryu, W.S. DDX3 DEAD-box RNA helicase is a host factor that restricts hepatitis B virus replication at the transcriptional level. J. Virol. 2014, 88, 13689-13698. [CrossRef]

39. Lim, W.; Kwon, S.H.; Cho, H.; Kim, S.; Lee, S.; Ryu, W.S.; Cho, H. HBx targeting to mitochondria and ROS generation are necessary but insufficient for HBV-induced cyclooxygenase-2 expression. J. Mol. Med. 2010, 88, 359-369. [CrossRef]

40. Huang, L.R.; Wu, H.L.; Chen, P.J.; Chen, D.S. An immunocompetent mouse model for the tolerance of human chronic hepatitis B virus infection. Proc. Natl. Acad. Sci. USA 2006, 103, 17862-17867. [CrossRef]

41. Dezhbord, M.; Lee, S.; Kim, W.; Seong, B.L.; Ryu, W.S. Characterization of the molecular events of covalently closed circular DNA synthesis in de novo Hepatitis B virus infection of human hepatoma cells. Antivir. Res. 2019, 163, 11-18. [CrossRef] [PubMed]

42. Park, Y.K.; Park, E.S.; Kim, D.H.; Ahn, S.H.; Park, S.H.; Lee, A.R.; Park, S.; Kang, H.S.; Lee, J.H.; Kim, J.M.; et al. Cleaved c-FLIP mediates the antiviral effect of TNF- $\alpha$ against hepatitis B virus by dysregulating hepatocyte nuclear factors. J. Hepatol. 2016, 64, 268-277. [CrossRef] [PubMed]

(C) 2020 by the authors. Licensee MDPI, Basel, Switzerland. This article is an open access article distributed under the terms and conditions of the Creative Commons Attribution (CC BY) license (http://creativecommons.org/licenses/by/4.0/). 